Volume 3 No 2 Maret 2018

p-ISSN : 2460-8750 e-ISSN : 2615-1731

http://dx.doi.org/10.26858/talenta.v3i2.6541

\title{
PENINGKATAN EFIKASI DIRI MELALUI PELATIHAN ORIENTASI MASA DEPAN NARAPIDANA REMAJA
}

\author{
Nurul Husnul Magfirah ${ }^{1}$, Asniar Khumas ${ }^{2}$, Dian Novita Siswanti ${ }^{3}$ \\ Fakultas Psikologi Universitas Negeri Makassar

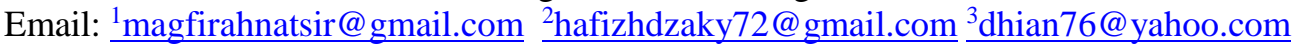

(C)2018 -JPT Fakultas Psikologi Universitas Negeri Makassar. Ini adalah artikel dengan

akses terbuka di bawah licenci CC BY-NC-4.0 (https://creativecommons.org/licenses/by-nc/4.0/ ).

\begin{abstract}
Abstrack. The purpose of this study was to examine the effectiviness of future orientation their to improve self-efficacy a prisoner. Self-efficacy is an individual's belief in the ability to solve a problem in a particular situation. Research respondents were selected using purposive sampling technique using experimental design pretest-posttest control group design. Subjects were 20 juvenile inmates from class II A, Maros corretional prison. This study uses a selfefficacy scale based on the theory of Bandura. The results of this study indicate that future orientation training is effective in improving self-efficacy in juvenile inmates with a significance of 0.003 . The results showed that future orientation training was considered effective to improve self-efficacy in adolescent inmates in Class II.A Maros Correctional Institution.
\end{abstract}

Keywords : future orientation, self-efficacy, adolescent inmates

Abstrak. Tujuan penelitian ini adalahmenguji efektivitas pelatihan orientasi masa depan untuk meningkatkan efikasi diri narapidana saat berada dalam lembaga pemasyarakatan. Efikasi diri merupakan keyakinan individu atas kemampuan yang dimiliki dalam menyelesaikan suatu permasalahan terhadap situasi tertentu. Responden penelitian dipilih menggunakan teknik purposive sampling dengan menggunakan desain eksperimen pretestposttest control group design. Subjek penelitian ini berjumlah 20 orang yang merupakan narapidana remaja di Lembaga Pemasyarakatan Kelas II.A Maros. Penelitian ini menggunakan skala efikasi diri berdasarkan teori dari Bandura. Hasil penelitian ini menunjukkan bahwa pelatihan orientasi masa depan efektif dalam meningkatkan efikasi diri pada narapidana remaja dengan signifikansi sebesar 0,003. Hasil penelitian menunjukkan bahwa pelatihan orientasi masa depan dinilai efektif untuk meningkatkan efikasi diri pada narapidana remaja di Lembaga Pemasyarakatan Kelas II.A Maros.

Kata Kunci: orientasi masa depan, efikasi diri, \& narapidana.

\section{PENDAHULUAN}

Masa remaja merupakan masa berkembang pesatnya orientasi masa depan. Hal ini sesuai dengan teori perkembangan kognitif Piaget yang menjelaskan bahwa masa remaja telah mencapai tahap pemikiran operasional formal (Yulianti, Sriati \& Widiasih, 2008). Pada tahap pemikiran operasional formal, remaja mampu untuk mengantisipasi masa depan atau kemampuan membuat skema kognitif untuk merumuskan 
rencana masa depan. Dengan pemikiran operasional formal membuat remaja mampu berpikir secara abstrak dan hipotesis, serta merumuskan proposisi secara logis, sehingga pada gilirannya remaja mampu membuat perencanaan dan melakukan evaluasi terhadap rencana-rencana di masa depan (Hurlock, 1998). Pada realitas di zaman sekarang dari tahun 2013 hingga 2014 tercatat sebanyak 593.115 yang dikategorisasikan sebagai remaja telah melakukan tindak kriminalitas di Indonesia (Bapennas, 2014).

Kasus kejahatan yang marak terjadi di Kota Makassar yang dilakukan oleh remaja sejak bulan Mei 2015 hingga Desember 2016, yakni pembusuran, pembegalan, perampokan, serta penganiyaan. Remaja yang melakukan kasus tersebut di bina di lembaga pemasyarakatan menyebabkan orientasi masa depan remaja menjadi tidak jelas. Masa depan yang baik tentunya sangat di idam-idamkan bagi setiap individu. Remaja yang hidup bersama dengan keluarga juga dapat memicu individu serta menjadi faktor pendukung untuk merencanakan masa depan yang baik. Namun berbeda halnya dengan remaja yang berada dalam lembaga pemasyarakatan. Suasana lembaga pemasyarakatan yang tidak ramah, adanya konsep pemisahan akan menyebabkan remaja merasa mempersalahkan diri dan menjadi inferioritas. Hal ini mengakibatkan orientasi masa depan narapidana yang tidak jelas (Yulianti, Sriati \& Widiasih, 2008).
Selain itu, masalah kedua adalah sering terjadi konflik pribadi antar narapidana remaja, antara lain takut ditolak oleh lingkungannya, rasa malu bergaul untuk kembali pada lingkungannya, gangguan harga diri, serta masyarakat yang condong untuk menjauhi mantan narapidana (Yulianti, Sriati \& Widiasih, 2008). Masalah ketiga adalah penelitian yang dilakukan oleh Ardilla dan Herdiana (2013) dari segi kondisi psikologis. Permasalahan-permasalahan psikologis yang sering muncul pada narapidana yang berada dalam lembaga pemasyarakatan, seperti depresi, kecemasan, anti social personality dan membuat efikasi diri narapidana menjadi lemah. penelitian yang dilakukan oleh Distia (Yulianti, Sriati \& Widiasih, 2008) menyebutkan bahwa 50\% sampai dengan $70 \%$ remaja yang dibebaskan dari proses pembinaan di lembaga pemasyarakatan cenderung menjadi residivis.

Berdasarkan permasalahan yang timbul pada narapidana remaja yang berada dalam lembaga pemasyarakatan, peneliti menarik kesimpulan bahwa munculnya permasalahan tersebut membuat narapidana memiliki efikasi diri yang rendah. Pengembangan terhadap efikasi diri remaja penghuni lembaga pemasyarakatan sangatlah penting. Hal tersebut sejalan dengan yang dikemukakan Carrooll, Gordon, Haynes dan Houghton (2013) bahwa remaja penghuni lembaga pemasyarakatan yang memiliki efikasi diri tinggi akan mudah keluar dari 
keterpurukan dan mampu merencanakan masa depan dengan baik, sedangkan remaja yang memiliki efikasi diri yang rendah sangat rentan dan mudah untuk kembali dalam pergaulan yang tidak baik dan bisa melakukan tindakan kriminal kembali.

Berdasarkan hasil survey yang dilakukan oleh peneliti pada tanggal 24 Desember 2015, peneliti menemukan bahwa sebanyak 57,6 \% narapidana remaja memiliki hambatan dalam menyelesaikan suatu permasalahan. Ghufron dan Risnawati (2010) mengemukakan bahwa individu yang memiliki efikasi diri yang tinggi akan mampu membangun lebih banyak kemampuan-kemampuan melalui usahausaha mereka secara terus menerus dan mengubah kejadian-kejadian di sekitarnya. Lebih mampu mengatasi stres, memiliki kualitas kesehatan yang berhubungan dengan hidup yang lebih tinggi, dan lebih mungkin untuk pulih dari trauma.

Selanjutnya, penelitian yang dilakukan oleh Brett dan Walle (1999) mengenai pelatihan orientasi masa depan terhadap peningkatan kinerja siswa. Responden pada penelitian ini adalah 262 orang yang belajar pada program MBA yang berusia 24 sampai dengan 27 tahun. Hasil penelitian menunjukkan bahwa untuk meningkatkan kinerja dari siswa diperlukan pelatihanpelatihan salah satunya dengan pelatihan orientasi masa depan.

Penelitian yang dilakukan oleh Gani (2015) tentang pelatihan orientasi masa depan untuk meningkatkan optimisme pada mahasiswa dengan subjek sebanyak 18 orang yang berkuliah di Fakultas Psikologi Universitas Negeri Makassar. Metode penilitian adalah purposive sampling. Hasil penelitian ditemukan bahwa pelatihan orientasi masa depan dinilai efektif untuk meningkatkan optimisme pada mahasiswa. Selain itu, individu juga akan mengembangkan perhatian dan usahanya terhadap tuntutan situasi dan dipacu oleh rintangan, sehingga individu akan berusaha lebih keras dalam kehidupan selanjutnya (Ghufron \& Risnawati, 2010). Radosevich, Allyn, dan Yun (2007) menjelaskan bahwa dalam menentukan orientasi masa depan diperlukan keyakinan dalam diri atas kemampuan yang dimiliki individu.

Berkaitan dengan hal tersebut perlu adanya pelatihan agar pengaruh negatif lembaga pemasyarakatan tidak terinternalisasi pada remaja. Individu yang menginginkan masa depan yang baik tidak akan merasa puas dengan keadaannya sekarang. Individu akan selalu membuat situasi yang lebih baik, sehingga dapat mendorongnya mengerahkan kemampuan, kekuatan serta usaha yang dimiliki untuk mencapai situasi yang baik pula demi masa depan yang lebih baik. Mengingat bahwa masa remaja adalah saat dimana orientasi masa depan berkembang pesat, rencana masa depan menjadi semakin terperinci, serta mulai membuat evaluasi lebih realistis dari 
kemampuan mereka untuk mencapai tujuan masa depan termasuk keputusan penting mengenai pendidikan dan pendudukan (Stoddard, Zimmerman \& Bauermeister, 2011).

Berdasarkan beberapa uraian diatas, maka peneliti tertarik untuk mengetahui efektivitas pelatihan orientasi masa depan terhadap peningkatan efikasi diri pada remaja di Lembaga Pemasyarakatan Kelas 2A Maros.

Reed, Mikels dan Lockenhoff (2012) mengemukakan bahwa efikasi diri mengacu pada keyakinan akan kemampuan yang dimiliki oleh individu untuk berhasil dalam melaksanakan tugas yang diberikan, mendorong individu untuk memilih tugas yang lebih menentang dan bertahan lebih dalam mengahadapi suatu tantangan. Efikasi diri merupakan suatu kepercayaan dalam kemampuan seseorang untuk mengatur dan melaksanakan program tindakan yang diperlukan untuk mengelola situasi (Chyung, Moll \& Berg, 2010). Chyung dkk (2010) juga menambahkan bahwa dengan efikasi diri yang tinggi mampu meningkatkan pondasi kognitif untuk menentukan tingkat upaya yang di perlukan untuk sukses. Alwisol (2004) mengemukakan bahwa efikasi diri berhubungan dengan keyakinan diri memiliki kemampuan melakukan tindakan yang diharapkan.

Bandura (1997) memaparkan bahwa terdapat beberapa dimensi efikasi diri, yaitu: a. Dimensi tingkat (magnitude)

Magnitude adalah kemampuan untuk menyelesaikan tugas yang kesulitannya berbeda. Individu akan mencoba tingkah laku yang diarasa mampu dilakukannya dan akan menghindari tingkah laku yang dirasa diluar batas kemampuannya.

b. Dimensi kekuatan (strength)

Strength berkaitan dengan kekuatan keyakinan individu atas kemampuannya. Individu yang memiliki keyakinan yang kuat akan kemampuannya, ketekunan dalam usahanya untuk mencapai tujuannya dicapai meskipun terdapat kesulitan dan rintangan.

c. Dimensi keluasan (generality)

Generality berkaitan dengan keluasan tingkah laku dimana individu merasa yakin terhadap kemampuannya. Individu dapat merasa yakin terhadap kemampuan dirinya tergantung pada pemahaman kemampuan dirinya yang terbatas pada suatu aktivitas dan situasi tertentu atau pada serangkaian aktivitas dan situasi yang lebih luas dan bervariasi.

Stoddard, Zimmerman, dan Bauermeister (2011) menjelaskan bahwa orientasi masa depan merupakan suatu pengalaman individu, rencana, motivasi, serta harapan individu yang menjadi dasar untuk menetapkan tujuan dan membuat rencana tentang masa depannya. Nurmi (1991) mengemukakan bahwa orientasi masa depan merupakan kemampuan seorang individu untuk 
merencanakan masa depan yang merupakan salah satu dasar dari pemikiran seorang manusia yang meliputi pendidikan, pekerjaan dan keluarga. Adamson, dkk (2007) mengemukakan bahwa orientasi masa depan adalah sejauh mana individu bisa membayangkan masa depan mereka dalam hal tujuan, harapan, harapan dan rencana terkait masa depannya.

Nurmi (1991) menjelaskan teori Cognitive Psychology dan Action Theory. Tahapan pembentukan orientasi masa depan tersebut meliputi tiga aspek, yaitu sebagai berikut :

a. Tahap motivasi

Tahap motivasi adalah tahap awal dimana seseorang mulai memiliki motif, ketertarikan dan tujuan akan satu hal tertentu di masa depan.

b. Tahap perencanaan

Pada tahap ini seseorang mulai merancang rencana dan menetapkan strategi untuk mencapai tujuan yang pada tahap sebelumnya sudah ditentukan.

\section{c. Tahap evaluasi}

Tahap evaluasi merupakan suatu proses dimana seseorang menilai seberapa besar kesempatan yang ia miliki dan seberapa mampu ia dalam mencapai tujuan serta menjalankan segala langkah-langkah yang sudah ditentukan untuk mencapai tujuan. Dalam proses evaluasi, self efficacy memainkan peranan yang penting, terutama dalam memberikan penguatan terhadap diri sendiri agar merasa mampu melakukan segala langkah pencapaian tujuan yang telah ditentukan, menghadapi tantangan, dan memiliki tekad dan optimisme untuk mencapai tujuan yang telah ditentukan.

\section{METODE}

Rancangan penelitian yang digunakan peneliti adalah Pretest-Posttest control group design. Variabel terikat dalam penelitian ini adalah efikasi diri yang merupakan keyakinan individu atas kemampuan yang dimiliki dalam menyelesaikan suatu permasalahan dalam situasi tertentu. Variabel bebas dalam penellitian ini adalah pelatihan orientasi masa depan. Subjek dalam penelitian ini memiliki kriteria sebagai berikut: (1) Remaja yang berusia 15-21 tahun yang telah melakukan tindak kriminalitas dan dibina dalam lembaga pemasyarakatan kelas 2A Maros. (2) Memiliki tingkat efikasi diri yang sedang. (3) Paham dengan instruksi yang diberikan. (4) Belum pernah mengikuti kegiatan pelatihan sebelumnya. (5) Mampu membaca dan menulis.

Dua puluh subjek diperoleh secara purposive sampling. Pengisian skala dilakukan dengan membagikan kepada 53 narapidana remaja di Lembaga Pemasyarakatan Kelas II A Maros. Berdasarkan pengolahan data, ditemukan hasil bahwa keseluruhan subjek berada pada 
kategori tingkat efikasi diri yang sedang. Selanjutnya dilakukan angket terkait pernah tidaknya mengikuti pelatihan orientasi masa depan sebelumnya serta bersedia untuk mengikuti pelatihan, maka ditemukan subjek sebanyak 20 orang.

Teknik pengumpulan data dalam penelitian ini menggunakan skala psikologis. Skala yang digunakan untuk mengukur efikasi diri dalam penelitian ini disusun oleh peneliti sendiri berdasarkan teori Bandura (1997), dengan 4 alternatif pilihan jawaban yaitu sangat sesuai (SS), sesuai (S), tidak sesuai (TS) dan sangat tidak sesuai (STS). Aitem yang digunakan untuk mengukur bersifat favorable dengan skor berturut-turut yaitu, 4, 3, 2, 1, dan unfavorable dengan skor $1,2,3,4$.

\section{HASIL DAN PEMBAHASAN}

Hasil penelitian di deskripsikan melalui bentuk rerata empirik, standar deviasi, efikasi diri minimum dan maksimum serta kategoriasi tingkat efikasi diri pada subjek penelitian.

Tabel 1. Perbandingan statistic deskriptif kelompok ekperimen-kontrol

\begin{tabular}{lcccc}
\hline & \multicolumn{2}{c}{ Kelompok Kontrol } & \multicolumn{2}{c}{ Kelompok Eksperimen } \\
& Pre test & Post test & Pre test & Post test \\
\hline Mean & 56,7 & 57,8 & 52,6 & 56,3 \\
Std.D & 1,702 & 2,780 & 1,429 & 1,702 \\
Min & 54,00 & 54,00 & 50,00 & 54,00 \\
Max & 59,00 & 63,00 & 55,00 & 60,00 \\
\hline
\end{tabular}

Hasil pengukuran efikasi diri pada kelompok kontrol menunjukkan bahwa rerata efikasi diri pada saat pretest yaitu 56,7. Rerata efikasi diri pada saat post test yaitu 57,8. Efikasi diri maksimum 63 dan efikasi diri minimum yaitu 54.Hasil pengukuran efikasi diri pada kelompok eksperimen menunjukkan bahwa rerata efikasi diri pada saat pretest yaitu 52,6. Rerata efikasi diri

Tabel 2. Perbandingan gain score kelompok eksperimen \& Kntrol

\begin{tabular}{lcc}
\hline Kelompok & Subjek & Gain Score \\
\hline \multirow{5}{*}{ Eksperimen } & MFF & 5 \\
\cline { 2 - 3 } & MR & 3 \\
\cline { 2 - 3 } & AA & 2 \\
\cline { 2 - 3 } & MRW & 4 \\
\cline { 2 - 3 } & MA & 3 \\
\cline { 2 - 3 }
\end{tabular}

pada saat post test yaitu 56,3. Efikasi diri maksimum 60 dan efikasi diri minimum yaitu 54.Berdasarkan analisis data empirik pada kedua kelompok, yakni kelompok eksperimen dan kontrol keseluruhan subjek berada pada kategori sedang. Adapun hasil dari gain score (pre test dan post test) untuk kedua kelompok adalah sebagai berikut: 


\begin{tabular}{|c|c|c|}
\hline & II & 5 \\
\hline & AMA & 5 \\
\hline & $\mathrm{R}$ & 2 \\
\hline & $\mathrm{AF}$ & 3 \\
\hline \multirow{10}{*}{ Kontrol } & A & 3 \\
\hline & $\mathrm{MH}$ & 0 \\
\hline & $\mathrm{MFH}$ & 0 \\
\hline & $\mathrm{M}$ & 0 \\
\hline & MS & 1 \\
\hline & AMS & 0 \\
\hline & KR & 2 \\
\hline & DR & 1 \\
\hline & $\mathrm{ABU}$ & 0 \\
\hline & $\mathrm{S}$ & 4 \\
\hline
\end{tabular}

Hasil uji deskriptif pada data pre test $\&$ post test diperoleh hasil bahwa keseluruhan subjek berada pada kategori sedang. Di duga hal ini disebabkan karena kedua kelompok tidak disetarakan terlebih dahulu sebelum melakukan pelatihan. Skor pretest untuk dikelompok kontrol memiliki skor terendah sebesar 54 sedangkan pada kelompok eksperimen skor terendah sebesar 50. Skor tertinggi untuk kelompok kontrol sebesar 63 sedangkan skor tertinggi dikelompok eksperimen sebesar 60. Namun, dilihat dari gain score untuk masing-masing kelompok, sebesar $100 \%$ subjek dikelompok eksperimen mengalami perubahan skor pada saat post test. Sedangkan sedangkan $50 \%$ subjek di kelompok kontrol tidak mengalami perubahan skor dengan artian pada saat pemberi perlakuan yakni pelatihan tidak mengalami perubahan skor. Hal tersebut membuktikan bahwa dari dua kelompok, yakni kelompok eksperimen dan kelompok kontrol di temukan hasil bahwa pada kelompok eksperimen memiliki peningkatan skor efikasi diri setelah di berikan perlakuan, yakni pelatihan orientasi masa depan sedangkan pada kelompok kontrol setengah dari keseluruhan subjek tidak mengalami perubahan.

Analisis hipotesis dalam penelitian ini yaitu terdapat peranan pelatihan orientasi masa depan terhadap peningkatan efikasi diri pada narapidana remaja. Dimana, ada perbedaan kelompok kontrol dan kelompok eksperimen berdasarkan hasil gain score pretest posttest di terima $(\mathrm{u}=11,5, \mathrm{p}<0,00$. 
Tabel 3.1 Uji Mann Whitney

\begin{tabular}{lcccc}
\hline Efikasi Diri & Mean Rank & $U$ & $P$ & Ket \\
\hline Gain score Eksperimen & 14,35 & 11.500 & 0,003 & Signifikan \\
Gain score Kontrol & 6,65 & & &
\end{tabular}

Pelatihan dinilai efektif karena terdapat peningkatan rata-rata skor efikasi diri yang signifikan pada kelompok eksperimen setelah mengikuti pelatihan orientasi masa depan. Hasil analisis dengan menghitung gain score kelompok eksperimen dan kelompok kontrol diperoleh $U$-test sebesar 11,5 dengan nilai signifikasi sebesar $0,003 \rightarrow(\mathrm{p}<0,05$.) Hasil tersebut menunjukkan bahwa terdapat perbedaan efikasi diri narapidana remaja sebelum dan setelah mengikuti pelatihan orientasi masa depan. Pelatihan orientasi masa depan dinilai efektif untuk meningkatkan efikasi diri pada narapidana remaja di Lembaga Pemasyarakatan kelas II.A Maros

Lunenburg (2011) mengemukakan bahwa individu yang memiliki tingkat efikasi diri yang rendah cenderung menetapkan orintasi tujuan yang relatif rendah untuk dirinya sendiri. Sebaliknya individu dengan efikasi diri yang tinggi cenderung menetapkan tujuan pribadi yang tinggi pula. Penelitian yang dilakukan menunjukkan bahwa dengan belajar individu mampu mengasah kemampuan yang dimiliki untuk mencapai tingkat konsistensi terhadap keyakinan atas kemampuan dirinya. Lunenburg (2011) juga menambahkan bahwa individu akan cenderung untuk belajar sesuatu yang lebih banyak dalam menggali keterampilan dan kemampuannya melalui pelatihan dan pada akhirnya akan cenderung untuk mengunakan yang didapatkan dari hasil belajar melalui pelatihan untuk meningkatkan kinerja dalam mencapai sasaran yang diinginkan.

Schunk (1995) menjelaskan bahwa semakin besar usaha dan ketekunan individu maka semakin besar pula peluang untuk mencapai tujuan yang lebih baik. Tujuan yang akan dicapai akan mengarahkan usaha individu serta menentukan perilaku individu. Orientasi tujuan akan memberikan individu visi untuk fokus pada keinginannya. Sesuai dengan teori diatas maka sejalan pula dengan materi pelatihan yang diberikan, yakni strategi pencapaian tujuan, dimana individu diminta untuk membuat perencanaan atau langkah-langkah dalam menentukan target yang diinginkan. Semakin banyak perencanaan langkah-langkah peserta mengenai target yang akan dicapai maka semakin besar keinginan subjek untuk mencapai tujuan yang diinginkan.

Menurut Cognitive Psychology dan Action Theory. Tahapan pembentukan orientasi masa depan tersebut meliputi tiga 
aspek, yaitu sebagai berikut :

1. Pengujian ini dilakukan untuk mengetahui apakah terdapat perbedaan pre test dan post test kelompok eksperimen pada efikasi diri narapidana remaja di lapas kelas II.A Maros. Berdasarkan hasil pengujian Wilcoxon didapatkan hasil signifikan (2-tailed) atau probabilitas sebesar 0,005 yang diketahui lebih kecil daripada 0,05. Dengan hasil tersebut, maka terdapat perbedaan yang signifikan pre test dan post test efikasi diri kelompok eksperimen, dimana setelah diberikan perlakuan melalui pelatihan orientasi masa depan terdapat peningkatan hasil pre test dan post test efikasi diri kelompok eksperimen

2. Temuan tambahan kedua dilakukan untuk mengetahui apakah terdapat perbedaan pretest dan post test kelompok kontrol pada efikasi diri narapidana remaja di Lembaga Pemasyarakatan Kelas II.A Maros. Berdasarkan hasil pengujian Wilcoxon diperoleh hasil signifikansi (2 tailed) atau probabilitas sebesar 0,358 yang diketahui lebih besar dari 0,05. Dengan hasil tersebut maka tidak terdapat perbedaan signifikan pre test dan post test efikasi diri kelompok kontrol, dimana apabila tidak diberikan perlakuan berupa pelatihan orientasi masa depan tidak terdapat perbedaan efikasi diri yang signifikan pada kelompok control.

3. Temuan tambahan ketiga dilakukan untuk mengetahui apakah terdapat perbedaan pre test dan post test test pengetahuan pada kelompok eksperimen. Pengujian ini dilakukan dengan menggunakan uji Wilcoxon. Hasil uji Wilcoxon diperoleh hasil yang signifikan (2 tailed) probabilitas sebesar 0,041 yang diketahui lebih kecil dari 0,05 . Dengan hasil tersebut maka terdapat perbedaan signifikan pre test dan post test tes pengetahuan, dimana apabila diberikan perlakuan berupa pelatihan orientasi masa depan terdapat perbedaan pengetahuan sebelum dan setelah pelatihan.

Dalam studinya Bandura (Janjhua, dkk, 2014) menjelaskan bahwa individu yang dengan keyakinan diri atas kemampuannya yang tinggi akan mendekati tantangan yang sulit sebaliknya individu dengan tingkat efikasi diri yang rendah cenderung untuk menghindar dari suatu permasalahan yang dialami. Remaja dengan efikasi diri yang tinggi menjelaskan peristiwa yang baik dan berusaha keras dalam mencapai hasil positif. Bandura (Lunanburg, 2011) menjelaskan bahwa individu dengan efikasi diri yang tinggi umumnya bekerja keras untuk belajar bagaimana melakukan tugas baru, karena mereka yakin bahwa upaya mereka akan berhasil. Individu dengan efikasi diri yang 
rendah dapat mengerahkan sedikit usahanya ketika belajar karena mereka tidak yakin usaha akan membawa kesuksesan.

Skinner (Pudjiastituti， dkk, 2012) mengemukakan bahwa remaja yang memiliki efikasi diri yang tinggi lebih memungkinkan untuk merancang tujuan atau goals lebih tinggi dan konkrit, membuat rencana-rencana logis, dan berani menghadapi tantangan. Beck (Pudjiastuti, dkk, 2012) menyatakan bahwa efikasi diri memengaruhi pola pikir dan reaksi emosional individu, baik dalam menghadapi situasi saat ini maupun dalam mengantisipasi situasi yang akan datang. Orang-orang dengan efikasi diri yang rendah selalu menganggap dirinya kurang mampu untuk menangani situasi yang dihadapinya. Dalam mengantisipasi keadaan, mereka juga cenderung untuk mempersepsikan masalahmasalah yang akan timbul jauh lebih berat daripada yang sesungguhnya.

\section{Sum dan Shek (Gani, 2015)} mengemukakan bahwa kepercayaan terhadap masa depan untuk mengembang kan remaja yang positif perlu mendapat perhatian yang lebih besar karena ada bukti penelitian yang menunjukkan bahwa terdapat efek positif kepercayaan terhadap masa depan pada kesejahtraan remaja. Harapan dan keyakinan adalah komponen terhadap masa depan, maka perlu untuk membantu remaja dalam menginternalisasi harapan-harapan yang positif pada remaja guna membentuk masa depan yang lebih baik. Berdasarkan hal tersebut peneliti kemudian mengembangkan suatu metode pelatihan yang dinilai positif, yakni pelatihan orientasi masa depan untuk membantu, remaja khususnya remaja dalam lembaga pemasyarakatan dalam membuat perencanaan gambaran masa depan guna meningkatkan efikasi diri.

\section{SIMPULAN DAN SARAN}

Hasil analisis dan pembahasan pada penelitian ini menunjukkan :

1. Adanya perbedaan efikasi diri narapidana remaja pada kelompok eksperimen sebelum mengikuti pelatihan orientasi masa depan (pretest) dan setalah mengikuti pelatihan orientasi masa depan (posttest).

2. Tidak ada perbedaan efikasi diri narapidana remaja pada kelompok kontrol pada saat pretest dan pada saat posttest.

3. Adanya perbedaan efikasi diri narapidana remaja antara sebelum dan setelah mengikuti pelatihan orientasi masa depan.

4. Adanya peningkatan pengetahuan peserta setelah mengikuti pelatihan Orientasi Masa Depan

Hasil dari analisis di atas menyimpulkan bahwa pelatihan orientasi masa depan efektif 
untuk meningkatkan efikasi pada narapidana remaja.

\section{SARAN}

1. Bagi subjek pelatihan, diharapkan seluruh materi yang didapatkan pada saat pelatihan Orientasi Masa Depan dapat diaplikasikan pada kehidupan sehari-hari, sehingga keterampilan dalam meningkatkan efikasi diri dapat berkembang.

2. Bagi Lembaga Pemasyarakatan Kelas II.A Maros, agar kiranya membuat kegiatan serupa secara kontinu, sehingga efikasi diri pada narapidana remaja dapat meningkat lebih baik.

3. Bagi peneliti selanjutnya:

a. Lanjutan agar melakukan penelitian dengan merancang suatu program yang bersifat jangka panjang dalam mengembangkan efikasi diri.

b. Mempertimbangkan waktu untuk melakukan pelatihan bukan dalam sehari saja melihat kondisi peserta dalam menerima materi yang mudah lelah dan cepat bosan.

\section{DAFTAR RUJUKAN}

Adamson, L., Wreder, L., \& Kerpelman, J. (2007). Self concept consistency and future orientation during the transition to adulthood. Journal of Youth Research, 15 (1), 91-112.
Alwisol. (2004). Psikologi kepribadian. Malang: UMM Press.

Ardilla, F., \& Herdiana, I. (2013). Penerimaan diri pada narapidana wanita. Jurnal Psikologi Kepribadian dan Sosial, 2 (1), 1-7.

Bandura. (1997). Self-Efficacy: The Exercise of Control. New York: W.H. Freeman and Company.

Bappenas. (2014). Data Statistik Kriminalitas. Diaskes pada 04 Juli 2016.http://www.bappenas.go.id/file s/data/Politik_Hukum Pertahanan_d an_Keamanan/Statistik\%20Kriminal \%202014.pdf

Brett, J, F., \& Walle, D, V. (1999).Goal Orientation and goal content as predictors of performance in a training program. Journal of Applied psycholog,. 84(6), 863-873.

Carroll, A., Gordon, K., Haynes, M., \& Houhton, S. (2013).Goal setting and self-efficacy among delinquent, atrisk and not at-risk adolescents. Journal Youth Adolescence, 42(-), 431-443.

Chyung, S, Y., Moll, A., \& Berg, S, A. (2010). The role of intrinsic goal orientation, self-efficacy, and elearning practice in engineering education. The Journal of Effective Teaching, 10(1), 22-37.

Clark, D, O. (1999). Age, socioeconomic status, and exercise self-efficacy.The Gerontological Society of America, 36(2), 157-164.

Erich, D. C., Surface, E. A., \& Brown, K, G. (2010). Frame-of-reference training effectiveness: Effects of goal orientation and self-efficacy on affective, cognitive, skill-based, and transfer outcomes. Journal of 
Applied Psychology, 95(6), 11811191.

Gani, N. A. (2015). Efektifitas pelatihan orientasi masa depan untuk meningkatkan optimisme pada mahasiswa baru Fakultas Psikologi Universitas Negeri Makassar. (Skripsi tidak diterbitkan). Makassar: Fakultas psikologi Universitas Negeri Makassar.

Ghufron, M., \& Risnawati. (2010). Teoriteori psikologi. Jogjakarta: Ar-Ruzz Media Group.

Hurlock, E. B. (1998). Psikologi perkembangan: Suatu pendekatan sepanjang rentang kehidupan (edisi kelima). Jakarta: Erlangga.

Janjhua, Y., Chaudhary, R., \& Chauhan, M. (2014). Relationship between employees' self-efficacy belief and role stress: A Study. Journal of Psychology, 5(2), 169-173.

Lunenburg, F. C. (2011). Self efficacy in the workplace: Implications for motivation and performance. International Journal of Management, Business, and Administration, 14(1), 1-6.

Nurmi, J. E. (1991). How Do Adolescent See Their Future?: A Review Of The Development of The Future Orientation and Planning. Helsinki: Academic press, Inc.

Pudjiastuti, E. D. T., \& Bellanisa, J. (2012). Hubungan self efficacy dengan orientasi masa depan area pendidikan siswa kelas XI jurusan IPA sekolah bertaraf internasional SMA Negeri 5 Bandung. Jurnal Sosial Ekonomi dan Humaniora, 3 (1), 269-276.

Radosevich, D, J., Allyn, M., \& Yun, S. (2007). Goal orientation and goal setting: Predicting performance by integrating four-factor goal orientation theory with goal setting processes. Seoul Journal of Business, 13(1), 21-46.

Reed, A. F., Mikels, J. A., \& Lockenhoff, C. F. (2012). Choosing with confidence: Self-efficacy and preferences for choice. Journal of Judgment and Decision Making, 7(2), 173-180.

Schunk, D. H. (1995). Self efficacy, motivation, and performance. Journal of Applied Sport Psychology, 7(2), 112-137.

Stoddard, S. A., Zimmerman, M. A., \& Bauermeister, J. A. (2011). Thinking about the future as a way to succeed in the present: A longitudinal study of future orientation and violent behaviors among African American Youth. Am J Community Psychology, 48(3-4), 238-246.

Yulianti, S. A., \& Widiasih, R. (2008). Gambaran orientasi masa depan narapidana remaja sebelum dan setelah pelatihan di rumah tahanan negara kelas 1 Bandung. Jurnal Psikologi, 10(19), 97-104. 